ORIGINAL RESEARCH PAPER

\title{
OPTIMIZATION OF THE MICROWAVE ASSISTED EXTRACTION AND BIOLOGICAL ACTIVITIES OF POLYPHENOLS FROM LEMON VERBENA LEAVES
}

\author{
ZOHRA TOUATI ${ }^{1}$, MENANA GUEMGHAR $^{1}$, KENZA BEDJAOUI $^{1}$, NABILA DJERRADA $^{1}$ \\ KAHINA DJAOUD ${ }^{1}$, NAWEL ADJEROUD ${ }^{1}$, KHODIR MADANI ${ }^{1,2}$, LILA BOULEKBACHE- \\ MAKHLOUF $^{1 *}$ \\ ${ }^{1}$ Laboratoire de Biomathématiques, Biophysique, Biochimie, et Scientométrie, Faculté des \\ Sciences de la Nature et de la Vie, Université de Bejaia, 06000, Bejaia, Algérie \\ ${ }^{2}$ Centre de Recherche en Technologie Agro-Alimentaire (CRTAA), Route de Targua-Ouzemour, \\ Bejaia, Algérie \\ *corresponding author: lila.makhlouf@univ-bejaia.dz
}

Received on 1 April 2021

Revised on 2 June 2021

\begin{abstract}
The present study aims to optimize the extraction of phenolics by microwaveassisted extraction (MAE) using the response surface methodology (RSM), from Lemon verbena leaves. The optimized extract was tested for its antioxidant activity using two methods (DPPH and reducing power) and its antibacterial efficiency by using disk diffusion assay and broth microdilution, against two Gram-negative (Escherichia coli ATCC 25922, Pseudomonas aeruginosa ATCC 27853) and two Gram-positive (Staphylococcus aureus ATCC 25923, Bacillus subtilis ATCC $6633)$ strains. Under the optimized conditions $(40 \%(\mathrm{v} / \mathrm{v}) \div$ of ethanol concentration, $188 \mathrm{~s}$ of irradiation time, $600 \mathrm{~W}$ of microwave power and $1: 40 \mathrm{~g} / \mathrm{mL}$ of solid-to-liquid ratio) the total phenolic content (TPC) was $67.87 \pm 1.61 \mathrm{mg}$ GAE/g DW. The $\mathrm{IC}_{50}$ of the extract was $139.65 \pm 1.44 \mu \mathrm{g} / \mathrm{mL}$ and $56.60 \pm 2.79 \mu \mathrm{g} / \mathrm{mL}$ for DPPH inhibition and reducing power, respectively. The best antibacterial activity was shown by the extract obtained by MAE with lower MBC (1.56 to $18.75 \mathrm{mg} / \mathrm{mL}$ ) and MBC/MIC ratio. Lemon verbena extract can be used as an ingredient in cosmetics, food supplements and herbal medicinal products due to its interesting biological properties.
\end{abstract}

Keywords: lemon verbena leaves, phenolic compounds, optimization, microwave-assisted extraction, antioxidant activity, antibacterial activity

\section{Introduction}

The Verbenaceae family is one of the most important families in the plant kingdom. It has several economic values due to its numerous uses in the food

https://doi.org/10.35219/foodtechnology.2021.1.11 
industries (Pérez Zamora et al., 2018; Moshari-Nasirkandi et al., 2020). Indeed, species of this family are used as food supplements (Mari et al., 2012), sweetener (Combrinck et al., 2007), food flavoring (De Almeida et al., 2018), and edible coating for food storage and preservation (Ishkeh et al., 2019; Castro et al., 2011; Montanari et al., 2011), spice (Sarrazin et al., 2015), they are also used in food seasoning (Marongiu et al., 2010). In Addition, since ancient times, the plants from this family are known as aromatic species for ornamental use or in folk medicine. Lemon verbena is one of the verbenaceae plants which has several therapeutic virtues, biological activities (Mashayekhi-sardoo et al., 2020; Bekara et al., 2020) and sedative effect that acts especially on the central nervous system (Bekara et al., 2020). It has a wide geographical distribution from South America to North Africa and South of Europe (Mashayekhi-sardoo et al., 2020), and its uses date back to the Inca civilization (Elechosa et al., 2017). It is usually consumed as an infusion for its stimulating, relaxing properties and exalting smell (Rocha et al., 2019). Its leaves have a pleasant lemon smell when crushed, and they are used to flavor fish, poultry, salads, jams, puddings, and soft drinks (Funes et al., 2010; Cunha et al., 2012). Its aromas are also used in perfumes and potpourri to scent homes (Brant $e t$ al., 2010). Due to the pleasant lemony fragrance and its application in food industries and cosmetics, as well as its use as a home remedy for several health problems, the plant is currently available in other parts of the world, as well (Bahramsoltani et al., 2018). Several categories of phytochemicals have been identified in its different parts such as terpenes, phenylethanoids and phenylpropanoids, flavonoids, miscellaneous compounds (Bahramsoltani et al., 2018) and phenolics (Pereira et al., 2017; Bekara et al., 2020). These latter are one of the most significant compounds which confer bioactive potential to plants (Moshari-Nasirkandi et al., 2020). For this reason, recent research has focused on improving the methods of their extraction, in order to optimize their recovery quantitatively and qualitatively (Leyva-Jiménez et al., 2020b).

Several classical extraction processes have been used for the extraction of polyphenols from Lemon verbena leaves (Cheurfa and Allem, 2016; Jalal et al., 2019; Leyva-Jiménez et al., 2020b). MAE as a green technology is one of the most efficient eco-extraction methods, because it saves time, energy and solvent (Ekezie et al., 2017). MAE allows high extraction efficiency of TPC. This can generally be attributed to its heating effect, which occurs due to the dipole rotation of the solvent in the microwave field. This causes the solvent temperature to rise, which then increases the solubility of the compound of interest (Hayat et al., 2009). This process is used for the extraction of phytochemicals for the pharmaceutical and food industries (Dahmoune et al., 2015; Hayat et al., 2009). The RSM is a collection of statistical techniques used in many engineering applications to improve and to optimize processes. It is effective for responses that are influenced by several factors and their interactions (Liu et al., 2015). Several recent works had studied the optimization of response (s) from Lemon verbena leaves using RSM (Ivanović et al., 2018; Leyva-Jiménez et al.,2020a, Leyva-Jiménez et al., 2020b; Villegas-Aguilar et al., 2020; Valiyan et al., 2021). 
Recently, many serious side impacts in humans were reported by synthetic preservatives such as cancer and cardiovascular disorders (MohammadzadehAghdash et al., 2019; Atta et al., 2017). So, an increased attention was focused on the potential use of natural products, such as extracts of medicinal plants, in food industry. Therefore, medical herb extracts have the potential of being used in this field. The objective of this work was to optimize the extraction of phenolic compounds by MAE, using green extraction method, from Lemon verbena leaves, and to determine the total flavonoid content (TFC), the antioxidant activity and the antibacterial capacity of the optimized extract with potential bioactive interest. The results were then compared to those obtained by conventional extraction method.

\section{Materials and methods}

\section{Reagents and plant material}

The chemicals were obtained from Biochem Chemopharma and Sigma Aldrich. The Lemon verbena leaves were collected from July to August (2018), in the region of Toudja (Bejaia, Algeria). They were washed, dried at $40{ }^{\circ} \mathrm{C}$, until the stabilization of the weight, and then grounded. The powder was passed through 125,250 and $500 \mu \mathrm{m}$ sieves and stored in the dark at $4{ }^{\circ} \mathrm{C}$.

\section{Phytochemical analyses}

\section{Microwave-assisted extraction (MAE)}

The extraction of polyphenols was carried out using a laboratory microwave with a modified system (2450 MHz, Maxipower Model MAXMO23S, China), having a maximum power of $900 \mathrm{~W}$. One gram of powder was mixed with the solvents (water, acetone, ethanol, and methanol) at different concentrations (from 20 to 80 $\% \mathrm{v} / \mathrm{v}$ ) and solid-to-solvent ratios (from 15 to $45 \mathrm{~g} / \mathrm{mL}$ ). The mixtures, exposed to a different microwave powers ranging from 200 to $700 \mathrm{~W}$ for extraction, were filtered and stored at $4{ }^{\circ} \mathrm{C}$. The parameters with the highest influence on the TPC microwave extraction were selected for the RSM study.

\section{Maceration extraction (ME)}

This extraction was achieved by adopting the protocol of Cheurfa and Allem. (2016). One gram of powder was mixed with $40 \mathrm{~mL}$ of $40 \%$ ethanol $(\mathrm{v} / \mathrm{v})$, the mixture was shaken well and left to macerate for 3 days at room temperature, then the filtrate was stored at $4^{\circ} \mathrm{C}$.

\section{Determination of total phenolic content}

The determination of the TPC was carried out using the Folin-Ciocalteu method as described by Georgé et al. (2005). The TPC was expressed as milligrams of gallic acid equivalent per gram of dry weight (mg GAE/g DW).

\section{Determination of total flavonoid content}

The total flavonoid content (TFC) was determined by the method of Quettier-Deleu et al. (2000). The content was expressed as milligrams of quercetin equivalent per gram of dry weight (mg QE/g DW). 


\section{Experimental design}

The response surface methodology is a statistical approach that was carried out to define the effects of different variables on the microwave extraction process, in order to optimize the TPC extraction. A central composite design (CCD) was developed using the RSM, to optimize the TPC extraction yield. The factors corresponding to each independent variable were: $\mathrm{X}_{1}$-solvent concentration (\%, $\mathrm{v} / \mathrm{v}), \mathrm{X}_{2}$-irradiation time $(\mathrm{s}), \mathrm{X}_{3}$-microwave power $(\mathrm{W})$ and $\mathrm{X}_{4}$-solid-to-solvent ratio $(\mathrm{mg} / \mathrm{mL})$. The TPC yield was the dependent response variable $(\mathrm{Y})$. A secondorder polynomial model was realized to predict the optimal conditions for extracting polyphenols (Equation 1):

$$
Y=\beta_{\mathrm{o}}+\sum_{i=1}^{k} \beta_{i} X_{\mathrm{j}}+\sum_{i=1}^{k} \beta_{i i} X^{2} \sum_{i>\mathrm{j}}^{k} \beta_{i j} X_{i} X_{\mathrm{j}}+E
$$

where $\beta_{\circ}$ is the constant coefficient of the model, $\beta_{i}, \beta_{i i}$ and $\beta_{i j}$ are the coefficients of linear, quadratic and interactive terms, respectively, $X_{i}$ and $X_{j}$ represent the coded independent variables.

\section{Biological activities}

\section{Antioxidant activity}

Two methods were applied to assess the antioxidant activity of the extract: 2,2Diphenyl-1-picrylhydrazyl (DPPH) radical scavenging activity and ferric reducing antioxidant power (FRAP) (Brand-Williams et al., 1995; Yildirim et al., 2001). These activities were expressed in terms of $\mathrm{IC}_{50}(\mu \mathrm{g} / \mathrm{mL})$, where the $\mathrm{IC}_{50}$ of DPPH scavenging activity is the concentration of sample or standard that inhibit $50 \%$ of DPPH radicals, it was obtained by linear regression analysis of dose-response curve plotting between the $\%$ of inhibition and concentration. For reducing power, the $\mathrm{IC}_{50}$ is the extract concentration where the absorbance is 0.5 , and is calculated from the graph of absorbance at $700 \mathrm{~nm}$ against the extract concentration (Rezig et al., 2019). The lowest $\mathrm{IC}_{50}$ means that the sample had the highest antioxidant capacity (Fidrianny et al., 2015). All the assays were carried out in triplicate; gallic acid was used as the positive control.

\section{Antibacterial activity}

Bacterial strains. MAE and ME were tested for their antibacterial activities against Escherichia coli ATCC 25922, Pseudomonas aeruginosa ATCC 27853, Staphylococcus aureus ATCC 25923 and Bacillus subtilis ATCC 6633 strains, provided by the Pasteur Institute (Algeria).

Agar diffusion method. The antibacterial effect of the extracts was tested using the disk diffusion method (Wikler, 2006). Each bacterial suspension with a concentration of $10^{6} \mathrm{CFU} / \mathrm{mL}$ (at $625 \mathrm{~nm}$ ) was cultured on plates containing Mueller-Hinton medium. The paper disks $(6 \mathrm{~mm})$ were imbibed with $20 \mu \mathrm{L}$ of extract $(100 \mathrm{mg} / \mathrm{mL})$ prepared in the DMSO and placed on the inoculated agar. The plates were incubated at $37^{\circ} \mathrm{C}$ for $24 \mathrm{~h}$. DMSO-impregnated discs were used as the negative control. The antibacterial activity was determined by measuring the inhibition zones (IZ) in millimeters (mm), an extract is active when its IZ around 
the disk is greater than $6 \mathrm{~mm}$ (Amiour et al., 2014). The experiments were performed in duplicate.

$M I C$ and $M B C$. The MIC was determined by the method of Wikler (2006). The dilutions ranging from 25 to $0.05 \mathrm{mg} / \mathrm{mL}$ were performed using 96-well microplates device. However, the MBC was determined from the MIC values. The DMSO was used as the negative control. The microplates were incubated at $37{ }^{\circ} \mathrm{C}$ for $24 \mathrm{~h}$ and the tests were performed in triplicate. The MIC is the lowest concentration of the extract required to completely inhibit the growth of the bacteria and the MBC is the concentration required to kill them.

\section{Statistical analysis}

The experiments were performed in triplicate, the influence of each factor on the TPC yield for the MAE, was statistically evaluated by the analysis of variance (ANOVA) and the Tukey's post hoc test with a 95\% confidence level. To construct the CCD approach, JMP software (version 10.0, SAS, USA) was used. The Tukey's post hoc test $(p<0.05)$ was also used to compare the antioxidant activity and the antibacterial activity of the extracts obtained with MAE and ME processes.

\section{Results and discussion}

\section{Effect of independent variables}

Microwave extraction is influenced by several parameters such as: particle size, extraction time, solid-to-solvent ratio, microwave power and type of solvent. The preliminary study results of the microwave-assisted extraction of TPC are shown in Table1.

\section{Effect of particle size}

The polyphenols extraction rate increased with the decrease of the particle size. According to Table 1, the particle size that resulted in a maximum extraction efficiency was $125 \mu \mathrm{m}(64.84 \pm 1.82 \mathrm{mg} \mathrm{GAE} / \mathrm{g} \mathrm{DW})$. Indeed, the extraction rate is increased since the diffusion distance of the solute within the solid is decreased when the particle size is smaller (Pinelo et al., 2005; Çavdar et al., 2017). $125 \mu \mathrm{m}$ was chosen to evaluate the effect of the extraction solvent on the TPC yield.

\section{Effect of extraction solvent}

The extraction efficiency of polyphenols depends on two processes. First, the solubility of the biomaterials of interest, through the interaction between the solvent and the plant matrix. Second, the microwave energy absorption properties of the solvent, which is determined by its dielectric constant (Dahmoune et al., 2015).

The extraction with methanol and ethanol solvents gave the best TPC yields, with statistically equal values. The ethanol was chosen for the RSM assays, because it is the most widely used solvent due to its low toxicity, and it could be used safely in the food, pharmaceutical and cosmetic industries (Yuan et al., 2019; Guemghar et al., 2020; Neshat et al., 2020). 


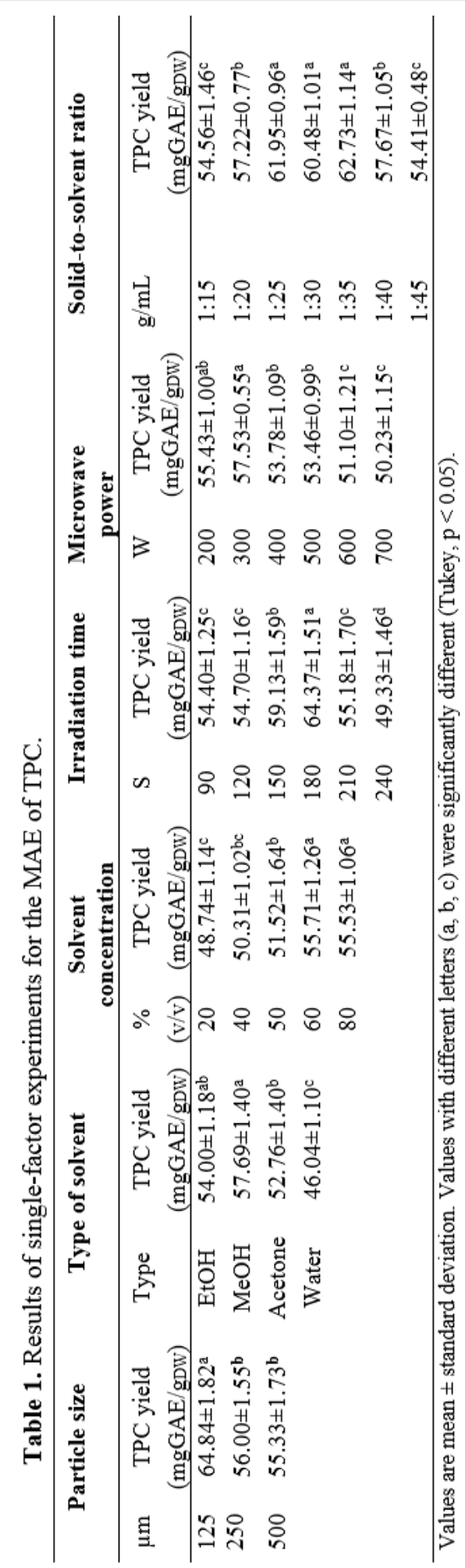

\section{Effect of ethanol concentration}

The presence of water in the solvent facilitates heat distribution throughout the sample, which enhances the dissolution and extraction yield of polyphenols (Guemghar et al., 2020). However, low concentration of ethanol can also induce a low extraction of TPC, probably due to the difference in dielectric properties of the solvent towards microwave heating (Dahmoune et al., 2015; Simić et al., 2016). So, it is necessary to find an appropriate concentration to obtain a better extraction rate. In this study, ethanol 60 and $80 \%$ gave the maximum TPC yields, and ethanol concentration of $60 \%$ was set for the following single-factor experiments. The range $40-80 \%$ was chosen for the CCD tests.

\section{Effect of irradiation time}

The irradiation time has a significant effect on the extraction rate of phenolic compounds by the fact that the extraction duration is proportional to the extraction yield (Dahmoune et al., 2015; Djaoud et al., 2020). In this study, the results showed that the extraction yield of TPC increased with the increase in the irradiation time, and reached its maximum after 180 s. Beyond this value, the extraction yield decreased progressively as the irradiation time was prolonged. This decrease is probably due to the thermal degradation of polyphenols (Dahmoune et al., 2014). Thus, 180 $\mathrm{s}$ was the optimal point used for the single-factor tests, and the range $150-210$ s was used to perform the RSM tests. 


\section{Effect of microwave power}

The microwave power effect on the polyphenols extraction yield was performed between 200 and $700 \mathrm{~W}$. The TPC yield increase from $200 \mathrm{~W}$ to reach a maximal level at $300 \mathrm{~W}$, after that, it begins to decrease with further increase of microwave power until $700 \mathrm{~W}$. Microwave power intensity; controls the amount of energy supplied to the sample that is converted into thermal energy. It also affects the interactions and distribution of the analytes between the sample and the solvent (Hayat et al., 2009; Lefsih et al., 2017). The increase of microwave power; increased the extraction efficiency of polyphenols. However, a high microwave power can increase the temperature of the processed product that leads to a thermal degradation of the compounds (Guemghar et al., 2020). Hence, $300 \mathrm{~W}$ was selected as the optimal level used for the single-factor tests, and 200-600 W was the range used to perform CCD design.

\section{Effect of solid-to-solvent ratio}

The TPC increased as the solid-to-solvent ratio increases progressively up to a maximum of 1:35 $\mathrm{g} / \mathrm{mL}$. Subsequently, the extraction efficiency decreased as the ratio increased. Indeed, increase in solid-to-solvent ratio decelerated mass transfer resulting from the lower heating efficiency under microwave conditions and the solubility of polyphenols (Dahmoune et al., 2015). In the same perspective, this can be explained by the fact that a larger volume of solvent requires greater absorption of microwave energy, but this energy may not be sufficient to destroy the cell walls and release the target components. The range $20-40 \mathrm{~g} / \mathrm{mL}$ was used to realize the CCD design.

\section{Optimization by RSM}

An experimental central composite design (CCD) was carried out based on the ethanol concentration, irradiation time, microwave power and solid-to-solvent ratio as the independent variables $\left(\mathrm{X}_{1}, \mathrm{X}_{2}, \mathrm{X}_{3}\right.$ and $\mathrm{X}_{4}$, respectively), the response ( $\mathrm{Y}$ ) represents the TPC. The values of the responses to different experimental combinations of coded variables are shown in Table 2.

Thirty experiments were performed with three levels for each factor, in order to study the influence of each of them and the result of their interactions. The levels of the independent variables were chosen based on the values obtained in the single-factor experiments.

\section{Modeling and model fitting}

In this study, the least square technique was used to calculate the regression coefficients of the intercept, linear, quadratic and interaction terms of the model (Table 3) as mentioned by Zhang et al. (2013). The $p$-value is used to check the significance of each coefficient, and the interaction pattern between the variables. The linear parameters which are $\mathrm{X}_{1}, \mathrm{X}_{2}, \mathrm{X}_{3}$, quadratic effects $\mathrm{X}_{2}^{2}$ and $\mathrm{X}_{4}^{2}$ as well as interactions $\mathrm{X}_{1} \mathrm{X}_{3}, \mathrm{X}_{2} \mathrm{X}_{3}$ and $\mathrm{X}_{2} \mathrm{X}_{4}$ were highly significant $(<0.0001 *)$. Solid-tosolvent ratio $\mathrm{X}_{4}$, quadratic effects $\mathrm{X}_{1}^{2}, \mathrm{X}_{3}^{2}$, interactions $\mathrm{X}_{1} \mathrm{X}_{2}, \mathrm{X}_{1} \mathrm{X}_{4}$ and $\mathrm{X}_{3} \mathrm{X}_{4}$ were not significant $(p>0.05)$. The $F$-value $(72.36)$ and the $p$-value $(<0.0001 *)$ show that the model is highly significant (Ji et al., 2018). 
Table 2. CCD with the experimental and predicted values for the TPC yield using the MAE.

\begin{tabular}{|c|c|c|c|c|c|c|}
\hline \multirow[t]{2}{*}{ Run } & \multirow[t]{2}{*}{$\mathbf{X}_{1}$} & \multirow[t]{2}{*}{$\mathbf{X}_{2}$} & \multirow[t]{2}{*}{$\mathbf{X}_{3}$} & \multirow[t]{2}{*}{$\mathbf{X}_{4}$} & \multicolumn{2}{|c|}{ Recovery of TPC (mg GAE/g DW) } \\
\hline & & & & & Experimental & Predicted \\
\hline 1 & $80(+1)$ & $150(-1)$ & $200(-1)$ & $40(+1)$ & $46.0 \pm 0.90^{\mathrm{kl}}$ & 47.00 \\
\hline 2 & $60(0)$ & $180(0)$ & $400(0)$ & $30(0)$ & $54.2 \pm 0.20^{\text {cdefghi }}$ & 53.21 \\
\hline 3 & $80(+1)$ & $210(+1)$ & $600(+1)$ & $20(-1)$ & $54.8 \pm 1.13^{\text {cdefgh }}$ & 54.59 \\
\hline 4 & $40(-1)$ & $210(+1)$ & $600(+1)$ & $40(+1)$ & $62.6 \pm 1.31^{\mathrm{ab}}$ & 63.15 \\
\hline 5 & $80(+1)$ & $210(+1)$ & $200(-1)$ & $20(-1)$ & $47.0 \pm 1.41^{\mathrm{jk} l}$ & 47.59 \\
\hline 6 & $60(0)$ & $180(0)$ & $400(0)$ & $20(-1)$ & $64.4 \pm 2.44^{\mathrm{a}}$ & 64.41 \\
\hline 7 & $40(-1)$ & $150(-1)$ & $200(-1)$ & $40(+1)$ & $57.2 \pm 1.73^{\text {bcdef }}$ & 56.45 \\
\hline 8 & $80(+1)$ & $210(+1)$ & $600(+1)$ & $40(+1)$ & $58.8 \pm 1.92^{\text {abcde }}$ & 58.66 \\
\hline 9 & $40(-1)$ & $210(+1)$ & $600(+1)$ & $20(-1)$ & $59.2 \pm 2.26^{\mathrm{abcd}}$ & 59,03 \\
\hline 10 & $40(-1)$ & $150(-1)$ & $200(-1)$ & $20(-1)$ & $59.8 \pm 0.41^{\mathrm{abc}}$ & 60.78 \\
\hline 11 & $80(+1)$ & $150(-1)$ & $200(-1)$ & $20(-1)$ & $52.9 \pm 3.25^{\text {efghij }}$ & 51.38 \\
\hline 12 & $80(+1)$ & $180(0)$ & $400(0)$ & $30(0)$ & $48.2 \pm 2.88^{\mathrm{ijkl}}$ & 49.02 \\
\hline 13 & $60(0)$ & $210(+1)$ & $400(0)$ & $30(0)$ & $46.2 \pm 3.12^{\mathrm{kl}}$ & 45.92 \\
\hline 14 & $60(0)$ & $180(0)$ & $600(+1)$ & $30(0)$ & $53.8 \pm 1.48^{\text {cdefghi }}$ & 54.24 \\
\hline 15 & $60(0)$ & $180(0)$ & $400(0)$ & $30(0)$ & $53.6 \pm 2.68^{\text {defghi }}$ & 53.21 \\
\hline 16 & $80(+1)$ & $150(-1)$ & $600(+1)$ & $20(-1)$ & $51.6 \pm 3.44^{\text {fghijk }}$ & 52.44 \\
\hline 17 & $60(0)$ & $180(0)$ & $400(0)$ & $30(0)$ & $53.8 \pm 0.50^{\text {cdefghi }}$ & 53.21 \\
\hline 18 & $80(+1)$ & $150(-1)$ & $600(+1)$ & $40(+1)$ & $50.8 \pm 3.11^{\text {ghijk }}$ & 49.80 \\
\hline 19 & $80(+1)$ & $210(+1)$ & $200(-1)$ & $40(+1)$ & $50.3 \pm 1.55^{\text {hijk }}$ & 49.91 \\
\hline 20 & $60(0)$ & $180(0)$ & $400(0)$ & $40(+1)$ & $63.8 \pm 1.70^{\mathrm{a}}$ & 64.27 \\
\hline 21 & $40(-1)$ & $180(0)$ & $400(0)$ & $30(0)$ & $56.3 \pm 1.11^{\text {cdefgh }}$ & 55.96 \\
\hline 22 & $60(0)$ & $180(0)$ & $400(0)$ & $30(0)$ & $53.5 \pm 2.83^{\text {defghi }}$ & 53.21 \\
\hline 23 & $60(0)$ & $150(-1)$ & $400(0)$ & $30(0)$ & $42.7 \pm 2.12^{1}$ & 43.46 \\
\hline 24 & $60(0)$ & $180(0)$ & $400(0)$ & $30(0)$ & $53.0 \pm 0.28^{\text {efghij }}$ & 53.21 \\
\hline 25 & $40(-1)$ & $150(-1)$ & $600(+1)$ & $40(+1)$ & $54.2 \pm 0.11^{\text {cdefghi }}$ & 54.45 \\
\hline 26 & $60(0)$ & $180(0)$ & $200(-1)$ & $30(0)$ & $51.7 \pm 0.14^{\mathrm{fghijk}}$ & 51.74 \\
\hline 27 & $40(-1)$ & $150(-1)$ & $600(+1)$ & $20(-1)$ & $57.6 \pm 1.40^{\text {bcdef }}$ & 57.03 \\
\hline 28 & $60(0)$ & $180(0)$ & $400(0)$ & $30(0)$ & $52.6 \pm 1.37^{\text {fghij }}$ & 53.21 \\
\hline 29 & $40(-1)$ & $210(+1)$ & $200(-1)$ & $40(+1)$ & $59.2 \pm 0.85^{\mathrm{abcd}}$ & 59.20 \\
\hline 30 & $40(-1)$ & $210(+1)$ & $200(-1)$ & $20(-1)$ & $56.8 \pm 1.36^{\text {bcdefg }}$ & 56.83 \\
\hline
\end{tabular}

$\mathrm{X}_{1}$ : Ethanol concentration, $\mathrm{X}_{2}$ : Irradiation time, $\mathrm{X}_{3}$ : Microwave power, $\mathrm{X}_{4}$ : Solid-to-solvent ratio, GAE: gallic acid equivalent and DW: dry weight.

$\mathrm{a}, \mathrm{b}, \mathrm{c}, \mathrm{d}, \mathrm{e}, \mathrm{f}, \mathrm{g}, \mathrm{h}, \mathrm{i}, \mathrm{j}, \mathrm{k}, \mathrm{l}$. Different letters, per column, indicate significant differences between mean values $(p<0.05)$. Equal letters indicate non-significant differences $(p>0.05)$.

The determination coefficient $\mathrm{R}^{2}$ and the adjusted determination coefficient $\mathrm{R}^{2}$ Adj were 0.9854 and 0.9720 , respectively, they were closely related. It demonstrates the good fit of the model to the experimental results. High $\mathrm{R}^{2}$ value indicates a high percentage of variability in responses that can be explained by these patterns ( $\mathrm{Ji}$ et al., 2018; Djaoud et al., 2020).

In fact, the obtained $\mathrm{R}^{2}$ means that $98.54 \%$ of the variations in the sample were due to the independent variables, and $1.46 \%$ of total variations could not be explained by this model (Song et al., 2011). Low coefficient of variation (C.V.\%) of $1.29 \%$ indicates a good model reproducibility (Simić et al., 2016). 
Table 3. Analysis of ANOVA for the fitted quadratic polynomial model of the TPC using MAE.

\begin{tabular}{|c|c|c|c|c|c|c|}
\hline Parameter & $\begin{array}{l}\text { Estimated } \\
\text { coefficients }\end{array}$ & $\begin{array}{l}\text { Standard } \\
\text { error }\end{array}$ & $D F$ & $\begin{array}{l}\text { Sum of } \\
\text { squares }\end{array}$ & F-value & Prob $>F$ \\
\hline $\begin{array}{l}\text { Model } \\
\text { Intercept }\end{array}$ & 53.207895 & 0.273901 & 14 & 787.66551 & 72.3626 & $<0.0001 *$ \\
\hline $\begin{array}{l}\text { Bo } \\
\text { Linear }\end{array}$ & 53.207895 & 0.273901 & & 787.66551 & 72.3626 & $<0.0001 *$ \\
\hline $\mathbf{X}_{1}$ & -3.472222 & 0.207833 & 1 & 217.01389 & 279.1179 & $<0.0001 *$ \\
\hline $\mathbf{X}_{2}$ & 1.2277778 & 0.207833 & 1 & 27.13389 & 34.8989 & $<0.0001 *$ \\
\hline $\mathbf{X}_{\mathbf{3}}$ & 1.25 & 0.207833 & 1 & 28.12500 & 36.1737 & $<0.0001^{*}$ \\
\hline $\begin{array}{l}\mathrm{X}_{4} \\
\text { Quadratic }\end{array}$ & -0.066667 & 0.207833 & 1 & 0.080000 & 0.1029 & 0.7528 \\
\hline $\mathbf{X}_{1}^{2}$ & -0.715789 & 0.547802 & 1 & 1.32746 & 1.7074 & 0.2110 \\
\hline $\mathrm{X}_{2}^{2}$ & -8.515789 & 0.547802 & 1 & 187.88928 & 241.6585 & $<0.0001 *$ \\
\hline $\mathbf{X}^{2}$ & -0.215789 & 0.547802 & 1 & 0.12065 & 0.1552 & 0.6992 \\
\hline $\begin{array}{l}\mathrm{X}_{4}{ }^{2} \\
\text { Interaction }\end{array}$ & 11.13211 & 0.547802 & 1 & 321.19667 & 413.1152 & $<0.0001 *$ \\
\hline $\mathbf{X}_{1} / \mathbf{X}_{2}$ & 0.0375 & 0.22044 & 1 & 0.02250 & 0.0289 & 0.8672 \\
\hline $\mathbf{X}_{1} / \mathbf{X}_{3}$ & 1.2 & 0.22044 & 1 & 23.04000 & 29.6335 & $<0.0001 *$ \\
\hline $\mathbf{X}_{1} / \mathbf{X}_{4}$ & -0.0125 & 0.22044 & 1 & 0.00250 & 0.0032 & 0.9555 \\
\hline $\mathbf{X}_{2} / \mathbf{X}_{3}$ & 1.4875 & 0.22044 & 1 & 35.40250 & 45.5338 & $<0.0001 *$ \\
\hline $\mathbf{X}_{2} / \mathbf{X}_{4}$ & 1.675 & 0.22044 & 1 & 44.89000 & 57.7364 & $<0.0001 *$ \\
\hline $\mathbf{X}_{3} / \mathbf{X}_{4}$ & 0.4375 & 0.22044 & 1 & 3.06250 & 3.9389 & 0.0658 \\
\hline Lack of fit & & & 10 & 10.027485 & 3.0665 & 0.1140 \\
\hline Pure error & & & 5 & 1.635000 & 3.0665 & 0.1140 \\
\hline Residual & & & 15 & 11.66249 & & \\
\hline $\mathbf{R}^{2}$ & & & & & 0.98541 & \\
\hline $\mathbf{R}^{2}$ Adjusted & & & & & 0.971792 & \\
\hline C.V. \% & 1.2992 & & & & & \\
\hline RMSE* & 0.8818 & & & & & \\
\hline Corr Total & & & 29 & 799.32800 & & \\
\hline
\end{tabular}

The linear effect of the ethanol concentration was significantly negative. Thus, the increase in the ethanol concentration could decrease the extraction yield. However, the linear effect of the irradiation time and microwave power, were significantly positive, which means that their increase possibly increase the extraction yield. The second-order polynomial equation was determined as follows (Equation 2):

$$
\begin{gathered}
Y(T P C)=53.21-3.47 X_{1}+1.23 X_{2}+1.25 X_{3}-8.51 X_{2}^{2}+11.13 X_{4}^{2}+ \\
1.2 X_{1} X_{3}+1.49 X_{2} X_{3}+1.67 X_{2} X_{4}
\end{gathered}
$$

\section{Response surface analysis}

The effect of the independent variables and their cross-effect on the phenolic performance was observed by a three-dimensional response surface curve, which is shown in Figure 1 A-F. The response was plotted on the z-axis with respect to the two studied independent variables, while keeping the other two remaining independent variables at their zero levels (Hayat et al., 2009). 

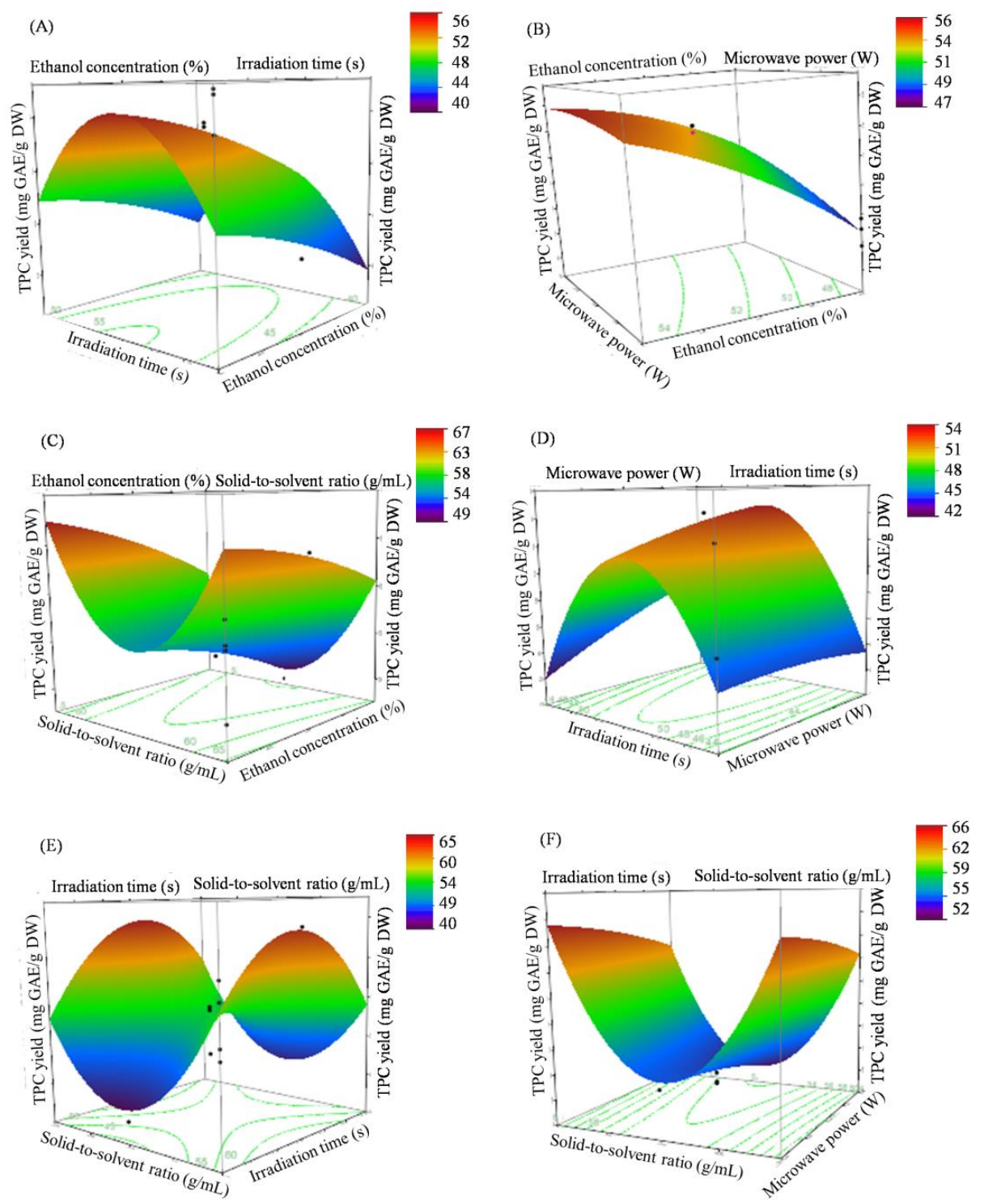

Figure1. Response surface plots for the effect of ethanol concentration and irradiation time (A); Ethanol concentration and microwave power (B); Ethanol concentration and solid-tosolvent ratio (C); Microwave power and irradiation time (D); Irradiation time and solid-tosolvent ratio (E) and Microwave power and solid-to-solvent ratio (F), on the TPC yield from Lemon verbena leaves obtained with MAE.

Figure 1A illustrates the interaction between ethanol concentration and extraction time on the TPC yield. Increasing the extraction time from 150 to $180 \mathrm{~s}$ induced an increase in the extraction yield, to reach a maximum value of $56.30 \mathrm{mg}$ GAE/g DW with $40 \%$ ethanol. Above $180 \mathrm{~s}$, there was a gradual decrease in the response which reaches $46.20 \mathrm{mg} \mathrm{GAE} / \mathrm{g} \mathrm{DW}$ at $210 \mathrm{~s}$ (60\% ethanol). Indeed, a long exposure to 
microwave irradiation could induce the thermos-degradation of the polyphenols (Dahmoune et al., 2014). The extraction rate of Lemon verbena leaves polyphenols depends mainly on the extraction time because its linear and quadratic effects were very significant $(<0.0001 *)$ (Table 3 ). Concerning the solvent concentration, the TPC yield decreases with increasing ethanol concentration. Indeed, the presence of an adequate amount of water in the solvent allows overheating which induce a release of the phenolic compounds (Lefsih et al., 2017).

Figure 1B illustrates the effect of ethanol concentration $\left(X_{1}\right)$ and microwave power $\left(X_{3}\right)$ on the TPC yield. The linear effect of the factors $X_{1}$ and $X_{3}$ as well as their cross-effect $\mathrm{X}_{1} \mathrm{X}_{3}$ was highly significant. The maximum extraction rate of 53.80 mg GAE/g DW was obtained at $40 \%$ ethanol and $400 \mathrm{~W}$ microwave power, after that it decreases continuously with increasing the ethanol concentration until $80 \%$ $(400 \mathrm{~W})$.

The interaction effect between ethanol concentration and solid-to-solvent ratio is shown in Figure 1C. As the ethanol concentration increased, the polyphenols yield decreased slightly. For the solid-to-solvent ratio, the TPC yield decreased significantly from $1: 20$ to $1: 30 \mathrm{~g} / \mathrm{mL}$. Above this value, the response increased to reach $63.80 \mathrm{mg} \mathrm{GAE} / \mathrm{g} \mathrm{DW}$ at a ratio of $1: 40 \mathrm{~g} / \mathrm{mL}$, which may be due to the best solubility of polyphenols (Dahmoune et al., 2015).

The linear effect of the factors irradiation time $\left(X_{2}\right)$ and microwave power $\left(X_{3}\right)$ as well as their cross effect $\left(\mathrm{X}_{2} \mathrm{X}_{3}\right)$ were highly significant. The response increased when the irradiation time increases from 150 to $180 \mathrm{~s}$ and microwave power increases from 200 to $400 \mathrm{~W}$ (Figure 1D). Above these values, the extraction efficiency decreased rapidly as the irradiation time increased to minimum value at $210 \mathrm{~s}$. The maximal values of the TPC were obtained at a microwave power of 400 $\mathrm{W}$ and an irradiation time of $180 \mathrm{~s}$.

The linear effect of the extraction time $\left(\mathrm{X}_{2}\right)$ and solid-to-solvent ratio $\left(\mathrm{X}_{4}\right)$ and their interactive effect $\mathrm{X}_{2} \mathrm{X}_{4}$ were highly significant $\left(<0.0001^{*}\right)$. As shown in Figure 1E, the TPC increased with increasing the extraction time from 150 to $180 \mathrm{~s}$ and the solid-to-solvent ratio from 1:30 to $1: 40 \mathrm{~g} / \mathrm{mL}$ to reach a maximum yield of 64.60 $\mathrm{mg} \mathrm{GAE} / \mathrm{g}$ DW. Beyond $180 \mathrm{~s}$ the response decreased rapidly.

The cross-effect of microwave power and solid-to-solvent ratio is shown in Figure 1F. The extraction rate, which was maximal (64.40 mg GAE/g DW) at an extraction ratio of $1: 20 \mathrm{~g} / \mathrm{mL}$ and a microwave power of $400 \mathrm{~W}$, decreased significantly with increasing the ratio up to $1: 30 \mathrm{~g} / \mathrm{mL}$. Above this value, the response increased quickly with increasing the solid-to-solvent ratio to $1: 40 \mathrm{~g} / \mathrm{mL}$ at a microwave power of $400 \mathrm{~W}$. The extraction rate decreased slightly with increasing the microwave power.

\section{Optimal extraction conditions and model validation}

The obtained results using the RSM to predict the optimal extraction conditions under microwave irradiation were: $40 \%(\mathrm{v} / \mathrm{v}), 188 \mathrm{~s}, 600 \mathrm{~W}$, and $1: 40 \mathrm{~g} / \mathrm{mL}$, for ethanol concentration, irradiation time, microwave power, and solid-to-solvent ratio, respectively. The predicted extraction rate under the above conditions was 
$67.87 \pm 1.61 \mathrm{mg}$ GAE/g DW. This value was significantly close to that of the TPC extraction rate calculated experimentally under the optimal conditions which was $67.86 \pm 0.92 \mathrm{mg} \mathrm{GAE} / \mathrm{g}$ DW. These results allowed the validation of the developed regression model for the optimization of process.

\section{Comparison between $M A E$ and $M E$}

Under the optimal conditions, MAE gave a TPC yield of $67.86 \pm 0.92^{\mathrm{a}} \mathrm{mg} \mathrm{GAE} / \mathrm{g}$ DW, this value was significantly higher $(p<0.05)$ than the yield obtained with ME $\left(34.55 \pm 0.90^{\mathrm{b}} \mathrm{mg} \mathrm{GAE} / \mathrm{g} \mathrm{DW}\right)$.

The flavonoids yield, obtained with MAE (10.91 $\pm 0.41^{\mathrm{a}} \mathrm{mg}$ QE/g DW), was statistically different $(p<0.05)$ than that of ME $\left(1.62 \pm 0.03^{\mathrm{b}} \mathrm{mg} \mathrm{QE} / \mathrm{g} \mathrm{DW}\right)$. This demonstrates a better efficiency of MAE process compared to ME. The higher TPC and TFC obtained with MAE compared to ME was due to the effect of the microwaves on the plant matrix. Indeed, the MAE guarantees a rapid transfer of energy from the solvent to the plant matrix, inducing a rapid and homogeneous heating, improving TPC recovery (Lefsih et al., 2017). On the other hand, a long extraction time may result in the degradation or conversion of the analytes (Hayat et al., 2009; Guemghar et al., 2020).

To the best of our knowledge, there are more studies on the essential oils composition and their biological activities (Bahramsoltani et al., 2018; Djadouni, 2020; Pérez Zamora et al., 2018; Bekara et al., 2020; Mashayekhi-sardoo et al., 2020; Sandner et al., 2020), than on the phenolic compounds of the studied plant. It should also be noted that the works carried out on its phenolic compounds were focused on their characterization (Quirantes-Piné et al., 2009; Quirantes-Piné et al., 2010) as well as on the biological activity of its different extracts or beverages (Moshari-Nasirkandi et al., 2020; Sandner et al., 2020; He et al., 2021). Indeed, few studies were conducted on TPC and TFC. In this study, we tried to compare our results with previous works done on this plant, unfortunately the data were different. This could be due to uncontrolled external factors: agro-climatic conditions, soil composition, harvesting periods, and to controlled factors such as the extraction methods and conditions. Zheng and Wang (2001) reported a content of $1.55 \pm 0.1 \mathrm{mg} \mathrm{GAE} / \mathrm{g}$ of fresh weight from phosphate buffer extract. However, Yoo et al. (2008) found higher values of $770.7 \pm 2.2 \mathrm{mg} \mathrm{GAE} / 100 \mathrm{~g}$; and $431.60 \pm 1.42 \mathrm{mg}$ catechin equivalents $/ 100 \mathrm{~g}$ of fresh weight in the hydromethanolic extract. Dadé et al. (2009) reported $1.70 \pm 0.19 \mu \mathrm{mol}$ of caffeic acid equivalent $/ \mathrm{mg}$ dry matter and $0.50 \pm 0.04 \mu \mathrm{mol}$ of rutin equivalent $/ \mathrm{mg}$ dry matter from an infusion extract. Recently Jalal et al. (2019) obtained $0.86 \mathrm{mg}$ of GAE/mg dry matter and $312.9 \mathrm{mg}$ of rutin equivalent per $100 \mathrm{~g}$ of dry matter from an ethanolic extract.

\section{Biological activity}

Antioxidant activity

The scientific interest in the antioxidant potential of natural extracts increases continually as they are used in the medical, food and cosmetic fields to replace 
synthetic antioxidants known for their toxicity. The results of the antioxidant activities of the optimized extract are shown in Table 4 (a).

According to the results of this study, the Lemon verbena extract showed a significantly higher $\mathrm{IC}_{50}(p<0.05)$ compared to gallic acid $\mathrm{IC}_{50}$ for all the antioxidant activities (Figure 2).

In the literature, few works have discussed the antioxidant activity of Lemon verbena extracts in terms of $\mathrm{IC}_{50}$. According to the obtained results shown in Table 4 (a), the increase in iron reduction was proportional to the extract concentration. The $\mathrm{IC}_{50}$ of the optimized extract was $56.60 \pm 2.79^{\mathrm{b}} \mu \mathrm{g} / \mathrm{mL}$, while that of gallic acid was $23.75 \pm 2.05^{\mathrm{a}} \mu \mathrm{g} / \mathrm{mL}$. The work carried by Cheurfa and Allem (2016), showed that the hydro-alcoholic macerate of Lemon verbena has an antioxidant potential of $6.63 \pm 0.10$ moles $\mathrm{Fe}$ (II)/g of extract. Rezig et al. (2019) showed an $\mathrm{IC}_{50}$ values for the reducing power of $209.33 \mu \mathrm{g} / \mathrm{mL}$ and $37.33 \mu \mathrm{g} / \mathrm{mL}$ for pure methanolic extract and ascorbic acid, respectively.

Table 4. Biological activitiy of Lemon verbena extracts obtained by MAE: antioxidant activity (a) and antibacterial activity (b).

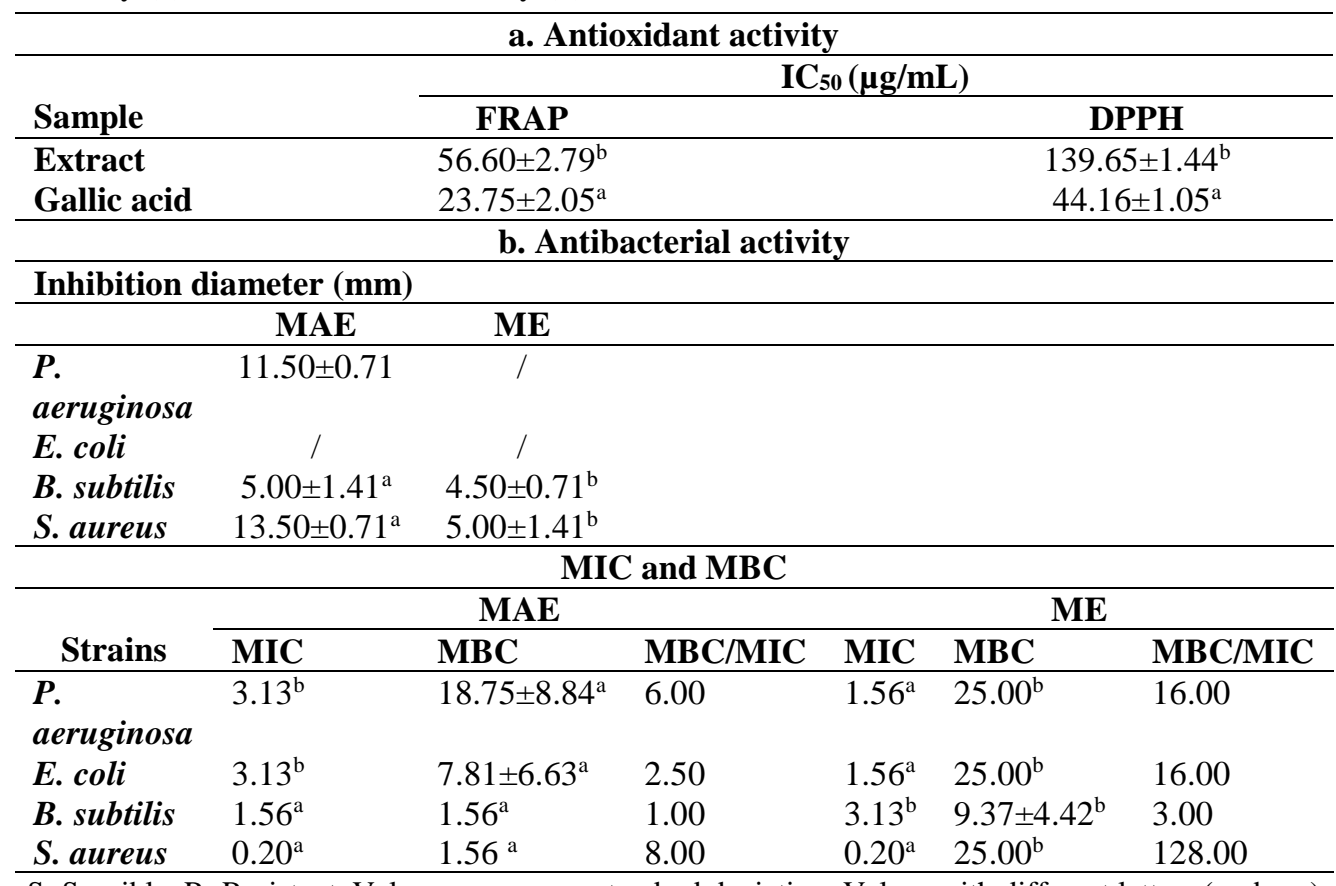

S: Sensible, R: Resistant. Values are mean \pm standard deviation. Values with different letters (a-, b-, c) were significantly different (Tukey, $\mathrm{p}<0.05$ ).

The $\mathrm{IC}_{50}$ values for the DPPH assay of the optimized extract and gallic acid were $139.65 \pm 1.44^{\mathrm{b}} \mu \mathrm{g} / \mathrm{mL}$ and $44.16 \pm 1.05^{\mathrm{a}} \mu \mathrm{g} / \mathrm{mL}$, respectively. Cheurfa and Allem. (2016) reported an $\mathrm{IC}_{50}$ of $23.52 \pm 0.04 \mathrm{mg} / \mathrm{mL}$ for the ethanolic extract of Lemon verbena, compared to that of BHT which was $6.96 \pm 0.10 \mathrm{mg} / \mathrm{mL}$. According to Hosseinzadeh and Ebrahimzadeh (2019), the 95\% ethanolic extract of Lemon 
verbena had a high $\mathrm{IC}_{50}$ of $21.97 \pm 2.4 \mu \mathrm{g} / \mathrm{mL}$ while that of BHA was $53.96 \pm 3.16$ $\mu \mathrm{g} / \mathrm{mL}$. The pure methanolic extract of Lemon verbena, had shown an antiradical activity of $5.78 \pm 0.08 \mu \mathrm{g} / \mathrm{mL}$ compared to that of BHT which was $11.5 \pm 1.23 \mu \mathrm{g} / \mathrm{mL}$ (Rezig et al., 2019).

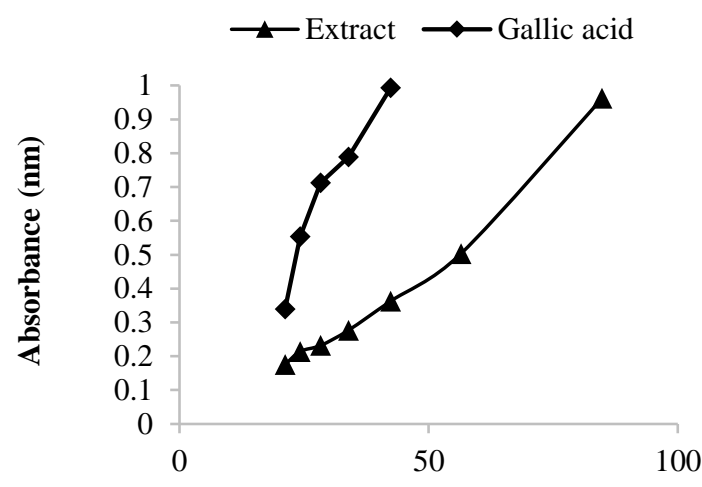

A

$\mu \mathrm{g} \mathrm{GAE} / \mathrm{mL}$

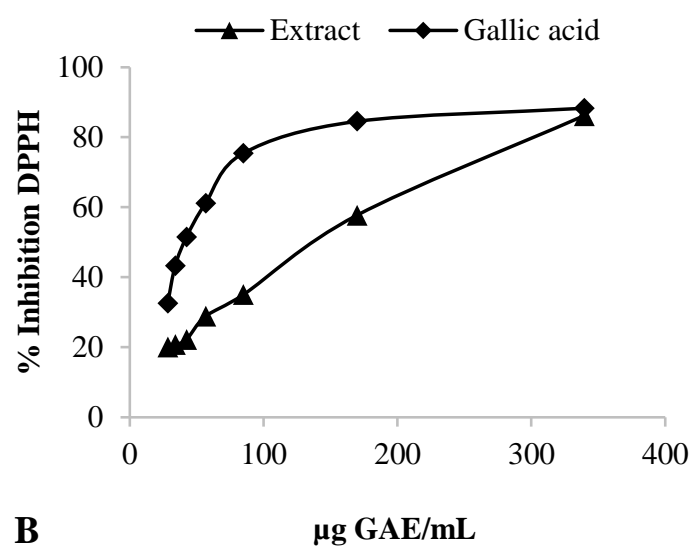

Figure 2. Antioxidant activities of Lemon verbena leaves extract obtained by MAE: Ferric reducing antioxidant power (FRAP) (A) and DPPH radical-scavenging assay (B).

\section{Antibacterial activity}

The antibacterial activity results were reported in Table 4 (b). According to the antibiogram profile, S. aureus, B. subtilis and E. coli were qualified to be sensitive strains, whereas $P$. aerugenosa was a resistant one. The Lemon verbena leaves extracts showed a moderate antibacterial activity, which were concomitant with the findings of Kumar et al. (2008). The extract obtained by MAE had the best antibacterial activity comparing to the ME. In fact, it exhibited a considerable antibacterial activity against $P$. aeruginosa and $S$. aureus. However, no activity was shown towards $B$. subtilis and $E$. coli strains. These results corroborate with those of Mirzaie et al. (2016). Several studies proved the antibacterial effect of polyphenols on Gram-positive and Gram-negative bacteria. Funes et al. (2010) 
showed that verbascoside, which is the major polyphenol in this plant, disrupts the structure of the phospholipid membrane. Indeed, the extract obtained with MAE is richer in polyphenols and flavonoids $\left(67.86 \pm 0.92^{\mathrm{a}} \mathrm{mg}\right.$ GAE/g DW and $10.91 \pm 0.413^{\mathrm{a}} \mathrm{mg} \mathrm{QEq} / \mathrm{g} \mathrm{DW}$, respectively), than the extract obtained by ME (34.55 $\pm 0.90^{\mathrm{b}} \mathrm{mg} \mathrm{GAE} / \mathrm{g} \mathrm{DW}$; and $1.62 \pm 0.03^{\mathrm{b}} \mathrm{mg}$ QEq/g DW respectively). This explains the highest antibacterial activity of the MAE extract. According to Tian et al. (2009), Polyphenols can alter bacterial cell walls, interact with membrane proteins through hydrogen bonds via their hydroxyl groups. Consequently, this induces changes in membrane permeability and cell destruction, and disrupts the co-aggregation of microorganisms (Naz et al., 2007).

\section{$M I C$ and $M B C$}

The obtained values of MIC and MBC are reported in Table 4 (b). The results show that these values vary depending on the germ and the extraction method. The MIC and $\mathrm{MBC}$ values ranged from 0.19 to $3.12 \mathrm{mg} / \mathrm{mL}$ and 1.56 to $25.00 \mathrm{mg} / \mathrm{mL}$, respectively. A MBC/MIC ratio less than or equal to 4, indicates the existence of a bactericidal effect of the tested extracts against the different germs (Mamadou et $a l ., 2014)$. The extract obtained by MAE showed a bactericidal effect against $E$. coli and $B$. subtilis with MBC/MIC ratio of 2.5 and 1, respectively, which confers antibiotic power on these strains. However, the macerated extract had a bactericidal effect only on the B. subtilis with a MBC/MIC ratio of 3. Comparing the two modes of extraction, it can be seen that the MAE extract has better antibacterial activity with low MBC levels (1.56 to $18.75 \mathrm{mg} / \mathrm{mL}$ ), compared to the $\mathrm{MBC}$ of the extract obtained by ME, with higher concentrations ( 9.37 to $25.00 \mathrm{mg} / \mathrm{mL}$ ). This effect could be due to the higher content of phenolic compounds in the extract obtained by MAE (Bouarab-Chibane et al., 2019; Efenberger-Szmechtyk et al., 2021).

According to these results, Gram-negative bacteria are more resistant by registering higher values of MIC and MBC than Gram-positive bacteria; these results were in agreement with those of Efenberger-Szmechtyk et al. (2021). This difference is may be due to the distinct cell wall structure between Gram-positive and Gramnegative bacteria. Indeed, a Gram-positive bacterium has a single-layer cell wall structure, whereas Gram-negative bacteria has a multi-layer structure containing an outer cell membrane that forms an impermeable barrier to most molecules (Mamadou et al., 2014).

\section{Conclusions}

The Lemon verbena is a widely used medicinal plant in traditional medicine for its richness in phenolic compounds. This work aimed to (i) optimize, by the response surface methodology, the microwave-assisted extraction of polyphenols, which enhances the TPC extraction yield in comparison to the conventional maceration method, allowing time and energy saving (both methods were carried out in $188 \mathrm{~s}$ and 3 days, respectively), (ii) study the in vitro antioxidant activities; of the extract obtained by MAE using DPPH and FRAP methods, (iii) compare both extraction 
processes concerning their antibacterial activities. The MAE showed a good antioxidant activity, and the best antibacterial activity compared to ME. These results promote the MAE of the bioactive compounds of this plant at an industrial level, with a view to their use in the medical, cosmetic and food fields.

\section{Acknowledgments}

We wish to acknowledge the General Direction of Scientific Research and Technological Development (DGRSDT) / Ministry of Higher Education and Scientific Research (MESRS) of Algeria.

\section{References}

Amiour, S. D., Alloui-Lombarkia, O., Bouhdjila, F., Ayachi, A., Hambaba, L. 2014. Étude de l'implication des composés phénoliques des extraits de trois variétés de datte dans son activité antibactérienne. Phytothérapie, 12, 135-142.

Atta, E. M., Mohamed, N. H., Abdelgawad, A. A. M. 2017. Antioxidants: An overview on the natural and synthetic types. European Chemical Bulletin. 6(8), 365-375.

Bahramsoltani, R., Rostamiasrabadi, P., Shahpiri, Z., Marques, A.M., Rahimi, R., Farzaei, M.H. 2018. Aloysia Citrodora Paláu (Lemon Verbena): A Review of Phytochemistry and Pharmacology. Journal of Ethnopharmacology, 222, 34-51.

Bekara, A., Amazouz, A., Douma, T.B. 2020. Evaluating the antidepressant Effect of Verbena officinalis L. (Vervain) aqueous extract in adult rats. Basic Clinical Neuroscience, 11, 91-8.

Bouarab-Chibane, L., Forquet, V., Lantéri, P., Clément, Y., Léonard-Akkari, L., Oulahal, N., Degraeve, P., Bordes, C. 2019. Antibacterial Properties of Polyphenols: Characterization and QSAR (Quantitative Structure-Activity Relationship). Models. Frontiers in Microbiology, 10, 829.

Brand-Williams, W., Cuvelier, M.-E., Berset, C. 1995. Use of a Free Radical Method to Evaluate Antioxidant Activity. LWT - Food science and Technology, 28(1), 25-30.

Brant, R.S., Pinto, J.E.B., Bertolucci, S.K.V., Albuquerque, C.J.B. 2010. Produção de biomassa e teor do oleo essencial de cidrão em função da adubação orgânica. Horticultura Brasileira, 28(1), 111-114.

Castro, C.E., Ribeiro, J.M., Diniz, T.T., Almeida, A.C., Ferreira, L.C., Martins, E.R., Duarte, E.R. 2011. Antimicrobial activity of Lippia sidoides Cham. (Verbenaceae) essential oil against Staphylococcus aureus and Escherichia coli. Revista Brasileira de Plantas Medicinais, 13, 293-297.

Çavdar, H.K., Yanık, D.K., Gök, U., Göğüş, F. 2017. Optimization of microwave assisted extraction of pomegranate (Punica granatum L.) seed oil and evaluation of its physicochemical and bioactive properties. Food Technology and Biotechnology, 55(1), 86-94.

Cheurfa, M., Allem, R. 2016. Évaluation de l'activité anti-oxydante de différents extraits des feuilles d'Aloysia triphylla (L’Hérit.) d'Algérie in vitro. Phytothérapie, 14(3), 181187.

Combrinck, S., Du Plooy, G.W., McCrindle, R.I., Botha, B.M. 2007. Morphology and Histochemistry of the Glandular Trichomes of Lippia scaberrima (Verbenaceae). Annals of Botany, 99(6), 1111-1119. 
Cunha, A.P., Nogueira, M.T., Roque, O.R. 2012. Plantas aromáticas e óleosessenciais, composição e aplicações. Fundação Calouste Gulbenkian, Lisboa. 678 p.

Dadé, M.M., Fioravanti, D.E., Schinella, G.R., Tournier, H.A. 2009. Total Antioxidant Capacity and Polyphenol Content of 21 Aqueous Extracts Obtained from Native Plants of Traslasierra Valley (Argentina). Boletín Latino americano y del Caribe de Plantas Medicinales y Aromáticas, 8(6), 529-539.

Dahmoune, F., Spigno, G., Moussi, K., Remini, H., Cherbal, A., Madani, K. 2014. Pistacia lentiscus leaves as a source of phenolic compounds: Microwave-assisted extraction optimized and compared with ultrasound-assisted and conventional solvent extraction. Industrial Crops and Products, 61, 31-40.

Dahmoune, F., Nayak, B., Moussi, K., Remini, H., Madani, K. 2015. Optimization of Microwave-Assisted Extraction of Polyphenols from Myrtus Communis L. Leaves. Food Chemistry, 166, 585-595.

De Almeida, W.S., de Lima, S.G., Barreto, H.M., De Sousa Andrade, L.M., Fonseca, L., Sobrinho, C.A., Santos, A.R.B., Muratori, M.C.S. 2018. Chemical composition and antimicrobial activity of the essential oil of Lippia lasiocalycina Cham. (Verbenaceae). Industrial Crops and Products, 125, 236-240.

Djadouni, F. 2020. Characterization and evaluation of antimicrobial activity of Algerian Aloysia triphylla essential oil against clinical female genital pathogens. Revue Agriculture, 11(1), 58-67.

Djaoud, K., Daglia, M., Sokeng, A. J. T., Kermiche, F., Arkoub, L., Madani, K., Boulekbache Makhlouf, L. 2020. RP-HPLC-PDA-ESI-MS/MS screening of bioactive compounds from Degla-Beida dates: Conventional and green extraction technologies. The Annals of the University Dunarea de Jos of Galati. Fascicle VI - Food Technology, 44(1), 58-81.

Efenberger-Szmechtyk, M., Nowak, A., Czyzowska, A. 2021. Plant extracts rich in polyphenols: antibacterial agents and natural preservatives for meat and meat products. Critical Reviews in Food Science and Nutrition, 61, 149-178.

Ekezie, F.G.C., Sun, D.W., Cheng, J.H. 2017. Acceleration of Microwave-Assisted Extraction Processes of Food Components by Integrating Technologies and Applying Emerging Solvents: A Review of Latest Developments. Trends in Food Science \& Technology, 67, 160-172.

Elechosa, M.A., Lira, P.D.L., Juárez, M.A., Viturro, C.I., Heit, C.I., Molina, A.C., Martínez, A.J., López, S., Molina, A.M., van Baren, C.M., Bandoni, A.L. 2017. Essential Oil Chemotypes of Aloysia Citrodora (Verbenaceae) in Northwestern Argentina. Biochemical Systematics and Ecology, 74, 19-29.

Fidrianny, I., Rizkiya, A., Ruslan, K. 2015. Antioxidant activities of various fruit extracts from three Solanum Sp. using DPPH and ABTS method and correlation with phenolic, flavonoid and carotenoid content. Journal of Chemical and Pharmaceutical Research, 7(5), 666-672.

Funes, L., Laporta, O., Cerdán-Calero, M., Micol, V. 2010. Effects of verbascoside, a phenylpropanoid glycoside from Lemon verbena, on phospholipid model membranes. Chemistry and Physics of Lipids, 163(2), 190-199.

Georgé, S., Brat, P., Alter, P., Amiot, M.J. 2005. Rapid Determination of Polyphenols and Vitamin C in Plant-Derived Products. Journal of Agricultural and food chemistry, 53(5), 1370-1373. 
Guemghar, M., Remini, H., Bouaoudia-Madi, N., Mouhoubi, K., Madani, K., BoulekbacheMakhlouf, L. 2020. Phenolic compounds from artichoke (Cynara scolymus L.) byproducts: optimization of microwave assisted extraction and enrichment of table oil. The Annals of the University Dunarea de Jos of Galati, Fascicle VI - Food Technology, 44(1), 193-211.

Hayat, K., Hussain, S., Abbas, S., Farooq, U., Ding, B., Xia, S., Jia, C., Zhang, X., Xia, W. 2009. Optimized Microwave-Assisted Extraction of Phenolic Acids from Citrus Mandarin Peels and Evaluation of Antioxidant Activity in Vitro. Separation and Purification Technology, 70(1), 63-70.

He, Q., Xiao, S., Zhang, C., Zhang, Y., Shi, H., Zhang, H., Lin, F., Liu, X., Yang, H., Wang, Q., Zhao, H. 2021. Modulation of the growth performance, biochemical parameters, and non-specific immune responses of the hybrid grouper (Epinephelus Fuscoguttatus $\bigcirc \times$ E. Lanceolatus $\bigcirc^{\top}$ ) by two kinds of Chinese herb. Aquaculture Reports, 19, 100604.

Hosseinzadeh, M.H., Ebrahimzadeh, M.A. 2019. Protective effects of ethanolic extract of Lemon Beebrush (Aloysia citrodora) leaf against hypoxia-induced lethality in mice. Tabari Biomedical Student Research Journal, 1(4), 1-7.

Ishkeh, S.R., Asghari, M., Shirzad, H., Alirezalu, A., Ghasemi, G. 2019. Lemon verbena (Lippia citrodora) essential oil effects on antioxidant capacity and phytochemical content of raspberry (Rubus ulmifolius subsp. sanctus). Scientia Horticulturae, 248, 297-304.

Ivanović, M., Alanon, M. E., Arraez-Roman, D., Segura-Carretero, A. 2018. Enhanced and green extraction of bioactive compounds from Lippia citriodora by tailor-made natural deep eutectic solvents. Food Research International, 111, 67-76.

Jalal, Z., Abdellfatah, A., Lyoussi, B. 2019. Phytochemical Screening and Antioxidant Activities No-volatile Extracts from Lemon Balm and Alyosia Citriodora from the Sefrou region. Green and Applied Chemistry, 7, 26-44.

Ji, X., Peng, Q., Yuan, Y., Liu, F., Wang, M. 2018. Extraction and physicochemical properties of polysaccharides from Ziziphus Jujuba cv. Muzao by ultrasound-assisted aqueous two-phase extraction. International Journal of Biological Macromolecules, 108, 541-549.

Kumar, N.K., Kumar, K.S., Raman, B., Reddy, I., Ramarao, M., Rajagopal, S.V. 2008. Antibacterial Activity of Lippia citriodora A Folklore Plant. Journal of Pure and Applied Mincrobiology, 2(1), 249-252.

Lefsih, K., Giacomazza, D., Dahmoune, F., Mangione, M.R., Bulone, D., San Biagio, P.L., Passantino, R., Costa, M.A., Guarrasi, V., Madani, K. 2017. Pectin from Opuntia ficusindica: Optimization of microwave-assisted extraction and preliminary characterization. Food Chemistry, 221, 91-99.

Leyva-Jiménez, F.J., Lozano-Sánchez, J., Cádiz-Gurrea, M. de la L., Fernández-Ochoa, Á., Arráez-Román, D., Segura-Carretero, A. 2020a. Spray-Drying Microencapsulation of Bioactive Compounds from Lemon Verbena Green Extract. Foods, 9(11), 1547.

Leyva-Jiménez, F.J., Lozano-Sánchez, J., Fernández-Ochoa, Á., Cádiz-Gurrea, M. de la L., Arráez-Román, D., Segura-Carretero, A. 2020b. Optimized Extraction of Phenylpropanoids and Flavonoids from Lemon verbena Leaves by Supercritical Fluid System Using Response Surface Methodology. Foods, 9(7), 931. 
Liu, T., Lin, B., Zheng, C., Zou, Q., Zhu, C., Yan, F. 2015. Influence of coupled effect among flaw parameters on strength characteristic of precracked specimen: Application of response surface methodology and fractal method. Journal of Natural Gas Science and Engineering, 26, 857-866.

Mamadou, R.S., Moussa, I., Sessou, P., Yehouenou, B., Agbangnan, P.D.C., Illagouma, A.T., Abdoulaye, A., Sohounhloué, D.C.K., Ikhiri, K. 2014. Etude phytochimique, activités antiradicalaire, antibactérienne et antifongique d'extraits de Sebastiania chamaelea (L.) Müll.Arg. Journal de la Société Ouest-Africaine de Chimie, 37, 10-17.

Mari, A., Montoro, P., Pizza, C., Piacente, S. 2012. Liquid chromatography tandem mass spectrometry determination of chemical markers and principal component analysis of Vitex agnus-castus L. fruits (Verbenaceae) and derived food supplements. Journal of Pharmaceutical and Biomedical Analysis, 70, 224-230.

Marongiu, B., Piras, A., Porcedda, S., Falconieri, D., Gonçalves, M.J., Salgueiro, L., Maxia, A., Lai, R. 2010. Extraction, separation and isolation of volatiles from Vitex agnus-castus L. (Verbenaceae) wild species of Sardinia, Italy, by supercritical $\mathrm{CO}_{2}$. Natural Product Research, 24(6), 569-579.

Mashayekhi-sardoo, H., Razavi, B.M., Ekhtiari, M., Kheradmand, N., Imenshahidi, M. 2020. Gastroprotective effects of both aqueous and ethanolic extracts of Lemon verbena leaves against indomethacin-induced gastric ulcer in rats. Iranian Journal of Basic Medical Sciences, 23(12), 8.

Mirzaie, A., Sadat Shandiz, S.A., Noorbazargan, H., Ali Asgary, E. 2016. Evaluation of chemical composition, antioxidant, antibacterial, cytotoxic and apoptotic effects of Aloysia citrodora extract on colon cancer cell line. Tehran University Medical Journal TUMS Publications, 74(3), 168-176.

Mohammadzadeh-Aghdash, H., Akbari, N., Esazadeh, K., Dolatabadi, J.E.N. 2019. Molecular and technical aspects on the interaction of serum albumin with multifunctional food preservatives. Food Chemistry, 293, 491-498.

Montanari, R.M., Barbosa, L.C.A., Demuner, A.J., Silva, C.J., Carvalho, L.S., Andrade, N.J. 2011. Chemical composition and antibacterial activity of essential oils from verbenaceae species: alternative sources of (E)-caryophyllene and germacrene-D. Química Nova, 34, 1550-1555.

Moshari-Nasirkandi, A., Alirezalu, A., Hachesu, M.A. 2020. Effect of Lemon verbena bioextract on phytochemical and antioxidant capacity of strawberry (Fragaria $\times$ ananassa Duch. Cv. Sabrina) fruit during cold storage. Biocatalysis and Agricultural Biotechnology, 25, 101613.

Naz, S., Siddiqi, R., Ahmad, S., Rasool, S.A., Sayeed, S.A. 2007. Antibacterial Activity Directed Isolation of Compounds from Punica granatum. Journal of Food Science, 72(9), 341-345.

Neshat, R.R., Bimakr, M., Ganjloo, A. 2020. Effects of Binary Solvent System on Radical Scavenging Activity and Recovery of Verbascoside from Lemon verbena Leaves. Journal of Human Environment and Health Promotion, 6 (2), 69-76.

Pereira, E., Barros, L., Antonio, A.L., Cabo Verde, S., Santos-Buelga, C., Ferreira, I.C.F.R., Rodrigues, P. 2017. Is Gamma Radiation Suitable to Preserve Phenolic Compounds and to Decontaminate Mycotoxins in Aromatic Plants? A Case-Study with Aloysia citrodora Paláu. Molecules. 22(3), 347. 
Pérez Zamora, C.M., Torres, C.A., Nuñez, M.B. 2018. Antimicrobial activity and chemical composition of essential oils from Verbenaceae species growing in South America. Molecules, 23(3), 544.

Pinelo, M., Del Fabbro, P., Manzocco, L., Nunez, M.J., Nicoli, M.C. 2005. Optimization of continuous phenol extraction from Vitis vinifera byproducts. Food Chemistry, 92(1), 109-117.

Quettier-Deleu, C., Gressier, B., Vasseur, J., Dine, T., Brunet, C., Luyckx, M., Cazin, M., Cazin, J.C., Bailleul, F., Trotin, F. 2000. Phenolic compounds and antioxidant activities of buckwheat (Fagopyrum esculentum Moench) hulls and flour. Journal of ethnopharmacology, 72(1-2), 35-42.

Quirantes-Piné, R., Funes, L., Micol, V., Segura-Carretero, A., Fernández-Gutiérrez, A. 2009. High-performance liquid chromatography with diode array detection coupled to electrospray time-of-flight and ion-trap tandem mass spectrometry to identify phenolic compounds from a Lemon verbena extract. Journal of Chromatography A, 1216(28), 5391-5397.

Quirantes-Piné, R., Arráez-Román, D., Segura-Carretero, A., Fernández-Gutiérrez, A. 2010. Characterization of phenolic and other polar compounds in a Lemon verbena extract by capillary electrophoresis-electrospray ionization-mass spectrometry. Journal of Separation Science, 33(17-18), 2818-2827.

Rezig, L., Saada, M., Trabelsi, N., Tammar, S., Limam, H., Bettaieb, I., Smaoui, A., Sghaier, G. 2019. Chemical composition, antioxidant and antimicrobial activities of Aloysia triphylla L. essential oils and methanolic extract. Italian Journal of Food Science, 31(3), 556-572.

Rocha, C., Coelho, M., Lima, R., Campos, F., Pintado, M., Cunha, L. 2019. Increasing phenolic and aromatic compounds extraction and maximizing liking of Lemon verbena (Aloysia triphylla) infusions through the optimization of steeping temperature and time. Food Science and Technology International, 25(8), 701-710.

Sandner, G., König, A., Wallner, M., Weghuber, J. 2020. Functional foods - dietary or herbal products on obesity: application of selected bioactive compounds to target lipid metabolism. Current Opinion in Food Science, 34, 9-20.

Sarrazin, S.L.F., da Silva, L.A., Oliveira, R.B., Raposo, J.D.A., da Silva, J.K.R., Salimena, F.R.G., Maia, J.G.S., Mourão, R.H.V. 2015. Antibacterial action against food-borne microorganisms and antioxidant activity of carvacrol-rich oil from Lippia origanoides Kunth. Lipids in Health and Disease, 14, 145.

Simić, V.M., Rajkovic', K.M., Stojic`evic', S. S., Velic `kovic', D. T., Nikolic', N. C., Lazic', M. L., Karabegovic, I. T. 2016. Optimization of microwave-assisted extraction of total polyphenolic compounds from chokeberries by response surface methodology and artificial neural network. Separation and Purification Technology, 160, 89-97.

Song, J., Li, D., Liu, C., Zhang, Y. 2011. Optimized microwave-assisted extraction of total phenolics (TP) from Ipomoea batatas leaves and its antioxidant activity. Innovative Food Science \& Emerging Technologies, 12(3), 282-287.

Tian, F., Li, B., Ji, B., Yang, J., Zhang, G., Chen, Y., Luo, Y. 2009. Antioxidant and antimicrobial activities of consecutive extracts from Galla chinensis: The polarity affects the bioactivities. Food Chemistry, 113(1), 173-179. 
Valiyan, F., Koohsari, H., Fadavi, A. 2021. Use of Response surface methodology to investigate the effect of several fermentation conditions on the antibacterial activity of several kombucha beverages. Journal of Food Science and Technology, 58, 1877-1891.

Villegas-Aguilar, M. del C., Leyva-Jiménez, F. J., Cádiz-Gurrea, M. de la L., SeguraCarretero, A., Arráez-Román, D. 2020. Comprehensive Analysis of Antioxidant Compounds from Lippia citriodora and Hibiscus sabdariffa Green Extracts Attained by Response Surface Methodology. Antioxidants, 9(12), 1175.

Wikler, M.A. 2006. Methods for dilution antimicrobial susceptibility tests for bacteria that grow aerobically: Approved Standard. CLSI (NCCLS), 26, M7-A7.

Y1ldırım, A., Mavi, A., Kara, A.A. 2001. Determination of Antioxidant and Antimicrobial Activities of Rumex crispus L. Extracts. Journal of Agricultural and Food Chemistry, 49(8), 4083-4089.

Yoo, K.M., Lee, C. H., Lee, H., Moon, B., Lee, C.Y. 2008. Relative antioxidant and cytoprotective activities of common herbs. Food Chemistry, 106(3), 929-936.

Yuan, Y., Farajtabar, A., Kong, L., Zhao, H. 2019. Thermodynamic solubility modelling, solvent effect and preferential solvation of p-nitrobenzamide in aqueous co-solvent mixtures of dimethyl sulfoxide, ethanol, isopropanol and ethylene glycol. The Journal of Chemical Thermodynamics, 136, 123-131.

Zhang, G., Hu, M., He, L., Fu, P., Wang, L., Zhou, J. 2013. Optimization of microwaveassisted enzymatic extraction of polyphenols from waste peanut shells and evaluation of its antioxidant and antibacterial activities in Vitro. Food and Bioproducts Processing, 91(2), 158-168.

Zheng, W., Wang, S.Y. 2001. Antioxidant Activity and Phenolic Compounds in Selected Herbs. Journal of Agricultural and Food Chemistry, 49(11), 5165-5170. 